\title{
On Emerson's Poem The Sphinx from the Perspective of Humanism
}

\section{Peiwei Zheng, Zhang Jingling}

Department of English Education, Shandong University of Technology, Zibo, China

\begin{abstract}
The Sphinx was one of Emerson's most enigmatic poems, in which Emerson presented questions in voices of the Sphinx and the great mother, and the poet's response to the questions. This article was a tentative study of the poem in terms of its meaning by analyzing the images of the Sphinx, the great mother and the poet from the perspective of Humanism.
\end{abstract}

Keywords- Emerson, the Sphinx, image, Humanism.

\section{INTRODUCTION}

The Sphinx was originally published in the third issue of The Dial (January 1841). Emerson regarded it as his favorite poem, and placed it at the head of his collected poems. Saundra Morris called it a threshold poem, which set a keynote for further understanding of the canon of Emerson's poetry. "Its notable degree of undecidability and the richness of the mythological material upon which it draws combine to make 'The Sphinx' a highly suggestive choice for what I have called a 'threshold poem"'(Porte \& Morris, 2004: 220). However, in those years after its first publication, the poem did not attract the attention of readers and critics mainly on account of its obscurity in meaning. Thoreau once said: "You may find this (exegesis) as enigmatical as the Sphin x riddle - indeed I doubt if she could solve it herself."(Guthrie, 2001:191). In a note Laurence Buell said: "when Emerson assumed the role of editor of his father's work, he removed the poem from its lead position for fear that its obscurity would frighten the readers away from the volume." (Guthrie, 2001:191). Many readers and critics were bewildered by the identity of the Sphinx, the great mother, and the poet in this poem. As time went by, more and more readers and critics came to realize the literariness and artistry of this enigmatical poem. Ralph L. Rusk presented a positive affirmation of the value of this poem. He held that this poem represented the essence of Emerson's thought. Thomas R. Whitaker also said: “It was Emerson's favorite poem-and for good reason: it reflects in miniature the full scope of his thought and literary method."(Whitaker, 1955). As for the meaning of the poem, scholars at home and abroad have done meticulous researches, but have not reached a consensus. This paper is a tentative analysis of The Sphinx from the perspective of humanis m embodied in it in order to present a new approach to better understand and appreciate this poem.

\section{AN OVERVIEW OF THE PROCESS OF HUMANIS M}

The word "humanis m" derived from the Latin word "humanus" which meant human-centered. According to Wikipedia: "Humanis $\mathrm{m}$ is a philosophical and ethical stance that emphasizes the value and agency of human beings, individually and collectively, and generally prefers critical thinking and evidence (rationalis $\mathrm{m}$, empiricism) over established doctrine or faith". Tony Davies once said: "Humanism is saluted as the philosophical champion of human freedom and dignity, standing alone and outnumbered against the battalions of ignorance, tyranny and superstition"(Davies, 2001: 5). From here we can see that although there is no definite definition of the term Humanis $m$, one thing is certain, that is Humanis m stresses Man's dignity, worth and capacity for self-realization. It originated from ancient Greece. At that time, Ancient Greek philosophers advocated the idea of freedom and equality for all. They held that humans were the centre of the world, and the measure of all things, and the core of Humanis $\mathrm{m}$ was to emphasize values and needs of human 
beings. Their ideas were the origin of Western Humanism. In broad sense, personal interest, dignity, freedom of thought, tolerance and non-violent coexistence among people were all the connotations of Hu man ism. Later, with the rise of religion, people's attention turned to the worship of God, and no longer to the situation of human beings themselves. Humanis $m$ then turned to a low ebb. No wonder that Sophocles designed a riddle of the Sphin $\mathrm{x}$ in his play Oedipus the King. His real intention for that was to warn people to continue to pay attention to such problems as the existence of Human Beings.

The Renaissance Human ism orig inated in Italy in the 14th and 15th centuries, the main features of which were as follows: increasing concern with the beauty of nature, Man's earthly life and their values; growing interest in classical literature and arts; restoring the grandeurs of Greek and Roman past; attempting to recover Greek and Roman texts which were lost or ignored in the past; holding human-centered viewpoint and opposing God-centered idea. Representative Humanists were Dante(1265-1321), Boccaccio(1313-1375) and Petrarch(1304-1374). Humanists at that time believed that all the wisdom and cultural achievements belonged to the creation of human beings, not from the oracle of God, and that the suffering of the present world was not a ticket to eternal Heaven, because Heaven was originally the product of human imagination. The following words excerpted from Shakespeare's Hamlet best reflected Humanists' praise of nature and Man: "This goodly frame the earth, this most excellent canopy the air, the brave o'erhanging firmament, this majestical roof fretted with golden fire. What a piece of work is a man! how noble in reason! how infinite in facilities! in form and moving, how express and admirable! in action how like an angel! in apprehension how like a god! the beauty of the world! the paragon of animals!"'(II. 2).

The En lightenment of the eighteenth century ushered in the second climax of the Humanist movement, which was regarded as the second cultural movement. Rationalism was the guiding ideology of this movement. Humanists in this period regarded human reason as the yardstick of judging everything. They believed that reason was the only friend of human beings and that religious fanaticis $m$ and superstition were their eternal enemies.
They criticized autocracy and religious ignorance, and propagated freedom, equality and democracy. As Richard Norman said: "They (Humanists) appeal to reason and experience against tradition, in order to criticize prejudice and superstition"(Norman, 2004: 11). In the $19^{\text {th }}$ century, the emergence of Darwin's evolutionism had a great impact on creationism. Darwin's theory of evolution enabled Hu manist thinkers to see the world anew. Emerson was one of them. The difference between Emerson and the Humanists in the past was that while he believed in religion, he also emphasized the importance of the individual. In Emerson's eyes, the sacredness of the individual was not allowed to be challenged or violated by anyone. It was important for the individual to have their own personality, and they should not sacrifice their personality to cater to society. Emerson believed in the infinite potential of the individual, and he called on individuals to give full play to their potential in all aspects, especially their intellectual potential. He also called on people to be self-reliant. He thought that the ideal type of man was the self-reliant individual. His standpoint of self-reliance advocated the dignity of life, the equality of all living beings, and encouraged the full play of the great potential of human nature, which conformed to the tradition of capitalist democracy and equality. Emerson's standpoint of self-reliance pushed the Humanist thought in Europe for centuries to a new level. As was known to all, in Emerson's time, the quick development of capitalist economy and industrialization of New England turned men into nonhumans, which worried Emerson greatly. In this context, Emerson paid attention to the survival and development of human beings, which coincided with the concerns of Humanists. As for Emerson's humanistic concern with the problem of Man's existence, we will give a detailed analysis in the following sections of this article.

\section{HUMANISM REFLECTED IN THE POEM}

\subsection{The image of the Sphinx}

As is well-known to all, the Sphin $\mathrm{x}$ is a large ancient statue of a creature with a human head and a lion's body that stands near the pyramids in Egypt. Many legendary stories are sparked by the Sphinx. In mythology, the sphinx gives people puzzles to solve, and so a person who is mysterious or puzzling is sometimes referred to as a 
Sphin $x$. And also the Sphin $x$ is often used to describe complex, mysterious, and incomprehensible problems. In literary works, the Sphin x orig inally appeared in Oedipus the King (430B.C-425B.C) written by an ancient Greek tragedy writer Sophocles (496B.C- 406B.C). In the play, the Sphinx presented a riddle for passers-by to solve, and it happened that Oedipus solved it. Now people have already known the answer to the riddle: mankind. The problem lied in the fact that why Sophocles designed such a riddle concerning mankind, but not other creatures. To answer the question, it is necessary to know what was going on and what hot social problems worried Sophocles. Sophocles was born in a wealthy family, in the golden age of the city-state Athens. Athenians lived in an age of self-confidence. Their philosophers believed that "man is the standard of everything". But in his time, many Athenians were arrogant and enthusiastic about fame and wealth. Sophocles was deeply worried about this trend. In the script, he repeatedly gave his advice and warnings. In his plays, the most important concern was the issue of humanity and interpersonal relations. Most of the tragic heroes in his plays had their own personality defects which led to the occurrence of their tragedies. Though Hu manis $m$ as an ideological system emerged in the Renaissance period, many years after the death of Sophocles, yet in his time, he began to probe into the problems concerning man's existence. Therefore, in this sense, the Sphinx in Oedipus the King represented Sophocles himself. The riddle he designed suggested the problems concerning human cognition of the world and the society, man's progress, their survival and so on. In the play, when Oedipus solved the riddle, the Sphin x dived from the cliff into the sea and committed suicide, which represented Sophocles' lofty spirit of dedication for man's awareness of their survival problems, that is to say, Sophocles wished to lay down his life to awaken the numb consciousness of his fellow country men, and he would rather die than live to see man's degeneration.

Emerson, inspired by Sophocles' the Sphin x's riddle, wrote the well-known poem The Sphinx. He, like Sophocles, wrote the poem with the intention to awaken his fellow countrymen to continue to pay close attention to the problem of man's survival as was suggested in the riddle of the Sphinx. All the time, Emerson had a preference for the image of the Sphin x. And on the door of Concord's "Old Manse", where Emerson once lived in (from1834-1835), there was a brass Sphinx-head knocker. It was clear that the reason why he set the Sphinx-head knocker there was to remind the passers-by like Oedipus not to forget man's dilemma of survival suggested through the Sphinx's riddle. So in the poem The Sphinx, most possibly, the Sphinx was referred to as Emerson himself, for "his (Emerson's) work has always been taken as sphingine; and in his lectures, we might recall, Emerson was capable of indicting audiences in the voice of his Sphin x."(Porte \& Morris, 2001: 780). In the first stanza of the poem, though "the Sphinx is drowsy, her wings are furled, her ears heavy," yet still "she broods on the world." Emerson, Like the Sphinx, was always brooding on "the fate of the man-child" and "the meaning of man". As a Transcendentalist, Emerson valued the importance of the individual. He held that a person's first concern of his life should be his self-improvement, self-cultivation, self-reliance and self-perfection, which was the intrinsic value of life, and not the frenzied and avaricious pursuit of wealth. In Emerson's time, with the rapid development of capitalist economy, it was money not man that became the standard of everything. "The industrialization of $\mathrm{New}$ England was turning men into nonhumans. People were losing their individuality and were becoming uniform."(Chang, 2011: 57). Through all his life, Emerson's main concern was such problems as the emancipation of individuality, man's self-culture, the promotion of man's spiritual perfection, and man's pursuit of happy earthly life. In this sense, to say Emerson was a Humanist was not much exaggeration.

Emerson voiced his dissatisfaction with the numbness of modern people through the mouth of the Sphinx: "Who'll tell me my secret, /The ages have kept? / I waited the seer, /While they slumbered and slept;". In the following stanza, he expressed his concern of the growth of the child and the self-perfection of the adult. Though Emerson was extremely worried about the state of man's survival, yet he was an optimist and did not lose hope for man. He pointed out a proper way for man to go along: go back to nature and learn from nature. From stanza 3 to stanza 5, he presented us a vivid depiction of such animated things in nature as the upspringing palm, the 
undaunted and calm browsing elephant, the wing-plying thrush, the unashamed waves, the mild breeze, and the journeying atoms and so on. All these things including "sea, earth, air, sound, silence, plant, quadruped, bird" were enchanted by one music and stirred by one deity. In stanza 15, Emerson, through the mouth of the Sphinx, warned "the poet" not to depend on Time in his quest for the answer, because Time sometimes was unreliable. He should go back to nature to search for the answer. "So take thy quest through nature, /It through thousand natures ply; /Ask on, thou clothed eternity; /Time is the false reply." Through all his life, Emerson attached great importance to man's position in the universe. He once said: "He(man) is placed in the centre of beings, and a ray of relation passes from every other being to him. And neither can man be understood without these objects, nor these objects without man."(Emerson, 2010: 112). In his work Self-Reliance, Emerson also said: "A true man belongs to no other time or place, but is the centre of things. Where he is, there is nature. He measures you, and all men, and all events."(Porte \& Morris, 2001: 126). According to him, nature was a teacher who provided man with knowledge. "The happiest man is he who learns from nature the lesson of worship."(Emerson, 2010: 138). All this reflected his humanist thought.

\subsection{The image of "the great mother"}

Mother is one of the most important artistic images emerg ing in many literary and artistic works in the West. For example, in the history of art, the different images of mothers in Raphael's Sistine Madonna, Albrecht Durer's Mother and Henry Moore's Mother Sculpture Series are the expression of the artist's personal sincere feelings and artistic pursuit, and gave us the enjoyment of beauty. And in the history of British and American literature, such positive images of mothers as Eve in Paradise Lost, Mother Earth in Prometheus Unbound, and Mother in The Grapes of Wrath all gave us deep impression. The concept of "mother" is the product of human collective unconsciousness, not just the specific image or image of one's mother features. In the poem The Sphinx, the image of the mother first appeared in stanza 6 , then in stanza 8 . This mother was not a mother in general sense. She transcended the general concept of mother, and symbolized the lofty universal love. Here in stanza 6 , the babe in arms was bathed in joy under the protection of this fraternity embodied in the mother. The child was happy on account of his mother's love and protection, and the pleasant environment. In such a case, everything was beautiful in his eyes, and therefore he was certain to become joyful and innocent. "The babe by its mother/Lies bathed in joy; /Glided its hours uncounted, /The sun is its toy; /Shines the peace of all being, /Without cloud, in its eyes; /And the sun of the world /In soft miniature lies." Here, Emerson showed his satisfaction with the healthy growth of the baby who lived in a warm and peaceful environment full of humanistic care. Actually through all his life, Emerson valued the importance of the education of children, for the child was the hope of the future of mankind. Wordsworth, in his poem My Heart Leaps Up, wrote: "The child is father of the man.", emphasizing the importance of the education of the child. Emerson devoted much time and energy to educating children. He often told his children about the creed of self-reliance in life. In Emerson's eyes, "every child and baby is a transcendentalist, and everyone is attracted by the charm they radiate."(Cabot, 2017: 249). As for the education of the child, he held that education was not a game, and the future of the child could not be used as a test. For him, education could make them break through their inner limitations and constantly improve themselves. In this sense, Emerson looked like a caring mother, and thus his humanistic thought could be affirmed.

In stanza 7, Emerson, through the mouth of the Sphinx, expressed his dissatisfaction with all that "the man" did. He employed many such derogatory words as "crouch, blush, abscond, conceal, creep, peep, palter, steal, infirm, melancholy, jealous, oaf, accomplice and poison" to present "the evil deeds of "the man". Emerson did this with the intention to remind people to probe deeply into the reason why the man degenerated from an innocent child to a person harmful to society. In stanza 8, Emerson, in the voice of "the great mother", put forward his questions: "Who has drugged my boy's cup? /Who has mixed my boy's bread? /who, with sadness and madness, /Has turned my child's head?'.It was these questions that had beset Emerson all the time. They reflected Emerson's anxiety about the severe social problems which affected his fellow countrymen of his time. Stanza 6 and Stanza 7 
constituted a striking contrast in terms of the healthy growth of the child and the harrowing degeneration of the man. Emerson thought that there must be something wrong with family education, school education and social education, etc. According to James E. Cabot, Emerson strongly opposed the competitive approach to education in New England in his time. Emerson called this approach "pois on of civilization" and "therapy of the quack"(Porte \& Morris, 2001: 251). In addition, the bad social living environment had a negative impact on the growth of children and the progress of adults. An Arabian proverb says, "A fig tree, looking on a fig tree, becometh fruitful." (Porte \& Morris, 2001: 60). This proverb implied that external environmental factors had a great influence on people's lives. In Emerson's time, in the wake of developing capitalism, the process of dehumanization emerged, and the relationship between man and nature, man and society, and man and man was severely alienated from one another. $\mathrm{He}$ was one of those who were concerned with the problem of the alienation of man. He once said: "The state of society is one in which the members have suffered amputation from the trunk, and strut about so many monsters, ___ a good finger, a neck, a stomach, an elbow, but never a man." (Porte \& Morris, 2001: 57). Because of men's avaricious pursuit of power and wealth, men were degenerated into nonhumans, which worried him greatly as a conscientious humanist. Thankfully, Emerson pointed out the proper way for "the man" to be redeemed in the next few stanzas (from stanza 9 to stanza 13).

\subsection{The image of "the poet"}

"The poet" first appeared in stanza 9. Hearing what the Sphinx and the great mother said, he expressed his satisfaction with their words and questions, because what they were concerned with about man's state of survival was just the same as his concern. So the poet loudly and cheerfully asked the Sphinx to say on. He even regarded the Sphin x's dirges as pleasant songs. Here, the poet could be regarded as the implied author (Emerson) or his second self, as was called by Wayne C. Booth who was a famous contemporary A merican novelist and theorist. In his book The Rhetoric of Fiction, Booth pointed out that when the author wrote, he would create his own "implied stand-in.".
"This implied author is always distinct from the 'real man'---whatever we may take him to be---who creates a superior version of himself, a 'second self', as he creates his work"'(Booth, 1983: 151). According to Booth, the poet in the poem was a dramatized figure, as he had a dual identity, that is to say, he acted as both a character and a narrator. And he was reliable, because he spoke and acted in accordance with the implied author's values and codes of action. Therefore, in the next few stanzas, "the poet", instead of the author Emerson, replied to the questions put forward by the Sphinx and the great mother.

In stanza 9, the poet pointed out that deep love imperceptibly "lied under these pictures of time". He called on people to find love and value it in pictures of Time. However, in Emerson's time, a number of people could not tell right from wrong because of their profound indulgence in the crazy pursuit of material wealth, which blinded their eyes. They could neither see the rays nor feel the love from the Best. They even regarded love of the Best as the monster. "The fiend that man harries /Is love of the Best.". In Emerson's eyes, it was the loss of love between man and nature, man and society, and man and man that brought about the deterioration of Man. Emerson, through the mouth of "the poet", expressed his view that love played a vital role in enhancing the spiritual realm of Man. Love rays from the Best could illuminate "the pit of the Dragon", and could also protect Man from being tranced by "the Lethe of nature". According to Emerson, love was omnipresent in nature, and was the noblest word and a synonym of God. One's soul represented his own life, and he must follow the call of the soul. It had creative energy, full of vitality and beauty. Love dwelt in the abode of soul. And "Love works at the centre". If one's soul was devoid of love, he would soon be withered. So the garden of the soul needed to be watered with the water of love. "The one thing in the world, of value, is the active soul. This every man is entitled to; this every man contains within him, although, in almost all men, obstructed, and as yet unborn" (Porte \& Morris, 2001:59).. Therefore the poet strongly warned people to elevate their souls to a higher level, because "Soul sees the perfect, / Which his eyes seek in vain".

In stanza 11, the poet continued to warn people to pay close attention to the elevation of their spiritual life, 
and at the same time warned them not to keep their eyes just fixed on material things all the time. "To vision profounder /Man's spirit must dive; /His aye-rolling orb /At no goal will arrive". According to the poet, the prosperity of life did not lie in constantly working for people to meet their animal needs, but in acquiring new spiritual power, experiencing pleasure of high-level life. "And we are now men, and must accept in the highest mind the same transcendent destiny; and not minors and invalids in a protected corner, not cowards fleeing before a revolution, but guides, redeemers, a benefactors, obeying the Almighty effort, and advancing on Chaos and the Dark" (Porte \& Morris, 2001:121).. Next the poet called on people to exp lore the mysteries of the universe. For him, man must have the spirit of pursuing novelty and innovation. "The heavens that now draw him / With sweetness untold, /Once found, -for new heavens /He spurneth the old". In fact, Emerson, as always, insisted that creativity and initiative were the source of the development of world civilization. "Whatever talents may be, if the man create not, the pure efflux of the Deity is not his; ---cinders and smoke there may be, but not yet flame"[4]59-60. Then the poet warned people to guard against arrogance and rashness and to reflect on themselves frequently, because "pride ru ined the angels, / Their shame them restores; /And the joy that is sweetest/Lurks in stings of remorse".

Stanza 14 and stanza 15 were conversations between the Sphinx and "the poet". As was mentioned above, the Sphinx represented Emerson himself, and "the poet" represented the implied author or his second-self. In this sense, the two stanzas could be regarded as a monologue of the author, through which his true inner thoughts could be externalized. Here actually, Emers on, in the voice of the poet, expressed his ambivalent psychology. On the one hand, he complained about his vague vision though he had "five wits" kept by Jove, and on the other hand, he expressed his self-confidence as he still had the staunch spirit and brilliant eyebeam given by the Sphinx, which showed his optimistic attitude toward life. In Sphin x's tone, he warned people to broaden their horizons and quest for answers in nature so that they could enhance their cognition of the world. Stanza 16 had a strong symbolic meaning. Instead of depicting the Sphinx's traditional association with death, Emerson eventually presented the Sphinx's soaring and dispersing into nature. Finally the Sphin $x$ completed her metamorphosis from "the drowsy, heavy and brooding" Sphinx to the merry and thousand-voiced Sphinx. "She melted into purple cloud, /She silvered in the moon; /She spired into a yellow flame; /She flowed in blossoms red; /She flowed into a foaming wave; /She stood Monadnoc's head". She became ubiquitous as was the Over-soul or God, which symbolized Emerson's idealis $m$ for higher spiritual life. Though the Sphin $x$ was not very satisfied with the poet's reply to her, she still felt merry, because what the poet talked about involved such problems of humanity as man's nature, survival, love, spirit, soul and creativity, etc. Emerson ended his poem with a quatrain, which was different from other stanzas containing 8 lines. It seemed that he deliberately left room for people to meditate on the meanings suggested in the secret of the Sphinx, and also the meanings of their lives, which showed Emerson's continuing concern for human destiny as a conscientious humanist.

\section{CONCLUSION}

The Sphinx was unanimously acknowledged as the most enig matic and controversial poem among Emerson's poetry though he regarded it as his favorite poem. "As befits its subject, Emerson's 'The Sphin x' has always been considered especially puzzling, even for the notoriously enigmatic Emerson. Despite the abundance of critical attention the poem has received, scholars continue to debate precisely what the Sphinx is supposed to represent, what her question is, and whether the poet's reply to her is astute or absurd" Porte \& Morris, 2004: 221). In fact, what puzzled readers and scholars was the meaning implied in the riddle of the Sphinx. In response to this, this article attempted to give an analysis of the images of the Sphinx, the great mother and the poet in terms of their identity and their concerns from the perspective of Humanism. If the Sphin $\mathrm{x}$ in Oedipus the King stood for Sophocles, then the Sphinx in the poem The Sphinx represented Emerson himself. In the first stanza of the poem, in the Sphinx's tone, Emerson asked the seer who "slumbered and slept" to tell the secret kept for ages. All sorts of signs indicated that the secret referred to the meaning of life for mankind. 
As a Transcendentalist, Emerson stressed the importance of spirit, or the Over-soul in the universe, and also valued the importance of the individual in society. In his view, man should strive to enhance their spiritual life, rather than frenziedly pursue material wealth. The meaning of man's life lied in their self-perfection. "If man depends upon himself, cultivates himself, and brings out the divine in himself, he can hope to become better and even perfect"(Chang, 2011: 61). In this sense, it is rational to say Emerson was a genuine Humanist. In the poem, the great mother had no specific name. Obviously she represented the universal love - true maternal love. Although only once did she appear in a single stanza, yet her three-who questions concerning the child's growth crisis "shuddered the sphere". Here Emerson, in the mother's voice, expressed the anger at the ill social ethos at that time, which exerted bad impact on the growth of children. All this showed his humanistic concern for children's growth. As for the identity of the poet in the poem, he might well be regarded as the implied author, or the second self of Emerson, that is to say, in the poet, we could see Emerson's silhouette. The poet, in response to the questions put forward by the Sphin $x$ and the great mother, pointed out a proper way forward for man. The way was to value true love, to elevate spiritual life, to perfect individual soul, to exert due creativity, to explore unknown mystery, and etc. In a word, Emerson, through the portrayal of the Sphinx, the great mother and the poet, discussed the significance of life from the philosophical point of view, which showed his humanistic concern for human destiny.

\section{REFERENCES}

[1] Booth, W. C.(1983). The Rhetoric of Fiction, Second Edition. Chicago \& London: The University of Chicago Press.

[2] Cabot, J. E.(2017). A Memoir of Ralph Waldo Emerson. Harbin: Heilongiiang Education Press.

[3] Davies, Tony. (2001). Humanism. Second Edition. London and New York: Routledge.

[4] Emerson, R..W. (2010). Nature. Translated by Wu Ruinan. Beijing: China Foreign Translation Publishing Company.

[5] Guthrie, J. R.(2001). Above Time: Emerson's and Thoreau's Temporal Revolutions. University of Missouri Press.
[6] Norman, Richard. (2004). On Humanism. London and New York: Routledge.

[7] Porte, J \& Morris, S.(2001). Emerson's Prose and Poetry. W. W. Norton \& Company. New York.London.

[8] Porte, J \& Morris, S.(2004). The Cambridge Companion to Ralph Waldo Emerson. Shanghai: Shanghai Foreign Language Education Press.

[9] Whitaker, T. R. The Riddle of Emerson's "Sphinx". American Literature, Vol. 27. No. 2 (May, 1955).p 179.

[10] Yaoxin, Chang.(2011). A Survey of American Literature. Tianjin: Nankai University Press. 